\title{
REMEMBERING AND FORGETTING MIRAMBO HISTORIES OF WAR IN MODERN AFRICA
}

\author{
Richard Reid \\ University of Oxford
}

\begin{abstract}
While the study of organised violence is considered essential to understanding the history of the West, and accordingly imbued with various layers of meaning and remembrance, war is widely regarded as inimical to the modern nation in Africa and stable development more broadly. Using examples drawn from primarily from East Africa, this paper considers the ways in which warfare in the deeper ('precolonial') past has been framed and envisioned in recent decades, in particular by governments whose own roots lie in revolutionary armed struggle and who began life as guerrilla movements. While in some cases particular elements of the deeper past were indeed mobilised in pursuit of contemporary political goals, in many other scenarios histories of precolonial violence were beheld as problematic and unworthy of remembrance. This paper highlights the paradox and ambiguity which has attended the memory of key aspects of Africa's deeper past.
\end{abstract}

\section{KEYWORDS}

Warfare, precolonial, history, memory, nationalism, nation, militarism, revolution, presentism. 


\section{INTRODUCTION}

FOR AFRICAN POLITICAL LEADERS in the 1950s and 1960s, supposedly the products of the colonial experience and the machinations of decolonisation, and for the postcolonial nations beyond, histories of violence in the deeper past had the potential to be mobilised in pursuit of modern political projects; but they were problematic, too. This paper offers some reflections on that ambiguity, using an East African focus in the main, but drawing on other examples where appropriate. Approaches to the deeper past were fragmentary and highly selective at best; at the other end of the spectrum, precolonial history was eschewed in favour of the presentist revolutionary fervour which underpinned political struggle.

For some, the precolonial past offered up heroes, who looked good if the lighting and the context were right. For backward-looking positivists, these were warriors of undeniable repute and achievement - men, and a few women too, who embodied the African genius through their deployment of violence in pursuit of glorious state-building projects, and the creation of innovative cultures. This was not violence for the sake of it: in addition to material outcomes - new political orders and the creation of wealth - this was war led by those who embodied the finest human qualifies. The experience of war was transformative and enlightening, and brought forth the best - and of course, for those defeated enemies, the worst - of human behaviour. Narratives of war were crafted to provide moral and didactic tales of goodness, valour, courage, embedded in oral tradition to offer guiding principles for governance and military command. The 'precolonial' past was, in short, seminal.

Yet for others, there was much which was best forgotten, or even vilified. In many ways, histories of war perpetuated the negative racial imagery which was rooted in a late nineteenthcentury European interpretation of African war as savage, wantonly destructive, and lacking in any of the higher attributes of 'civilised' warfare; Africa itself was accordingly a place of insufferable and ceaseless violence which reflected fundamentally the chronically backward nature of African culture and the African personality. These were ideas which were prevalent from the late eighteenth century, when they formed the intellectual core of the anti-slave trade movement; later, Christian missionaries and sundry Victorian explorers expanded on the central themes - arguing, increasingly, for robust humanitarian intervention in order to save Africa from itself. ${ }^{1}$ Those racial tropes proved remarkably pervasive, both in Europe and, more importantly, in Africa itself. The nationalists of the mid-twentieth century were loath to look back to a barbaric past, for they too wished to embrace what they saw as 'modernity'. Although there was a brief but intense period of interest in the deeper past as part of the nation-building projects of the 1960s, more generally there was a profound anxiety about 'Dark Continent' imagery among Africa's first generation of leaders. It was anxiety manifest in a reluctance to embrace a violent past and therefore a struggle to know how to engage with, let alone celebrate, that great temporal plain. Visions of a nineteenth century characterised by rampant violence as it unquestionably was - were reminiscent of the 'Dark Continent' tropes common since the 1870 s and 1880s. ${ }^{2}$ Moreover, the 'scramble' for Africa and the conquest involved had

\footnotetext{
${ }^{1}$ A sample of writings from East Africa which capture the dark imaginings of Europeans would include R.F.Burton, The Lake Regions of Central Africa, 2 vols. (London, 1860); J.H.Speke, Journal of the Discovery of the Source of the Nile (Edinburgh \& London, 1863); H.M.Stanley, Through the Dark Continent, 2 vols. (London, 1878, 1899); A.M.Mackay, A.M.Mackay, Pioneer Missionary of the Church Missionary Society to Uganda (London, 1890). For analysis, see R.J.Reid, 'Revisiting primitive war: perceptions of violence and race in history', War and Society, 26:2 (2007); and Patrick Porter, Military Orientalism: Eastern war through Western eyes (London, 2009).

2 Patrick Brantlinger, 'Victorians and Africans: the genealogy of the myth of the Dark Continent', Critical Enquiry, 12:1 (1985).
} 
effectively extinguished the idea of 'usable' African military glory. More practically, few of the new nations corresponded with the polities underpinned by revolutionary war in the previous century; in fact most of them comprised several such polities, and so these were histories of violence which in fact underlined the fragility of those new nations, rather than providing them with precedents for political achievement and, more specifically, the constructive deployment of organised violence. The new nations of the 1950s and 1960s were thus cut across by violent fault lines and rested on a series of volatile precolonial frontiers. While in the precolonial era those frontiers might have represented the founts of African political creativity, as argued by Kopytoff in his treatise on the subject, ${ }^{3}$ in the twentieth century they were seen only as destructive, as destabilising, and ultimately as inimical to postcolonial modernity. These were emphatically not, in Terence Ranger's famous formulation, "usable" histories at the level of the nation. ${ }^{4}$ The imposition of colonial rule had forced a violent rupture in terms of wider understandings of the historical relationship between political and military development over la longue durée.

There is nothing peculiarly African about this apparent paradox, of course: the remembrance of war is always contested, everywhere. The ways in which conflict is remembered globally are complex and numerous: there is no linear path, no easily chartable manner in which histories of violence can be mapped and understood. While some European states have long venerated older military traditions as part of the national heritage, revolutionary nationalisms have frequently involved similar kinds of rebirth as witnessed in Africa in the middle third of the twentieth century: renaissance and the 'rebooting' of History can be seen, for example, in the context of revolutionary France in the 1790s. And it is worth noting, too, that while national identity in Europe might occasionally be built around comparatively 'ancient' or more distant wars - the Hundred Years' War for England, for example - rather more commonly it was constructed around more recent conflicts, just as in twentieth century Africa: the FrancoPrussian War and the two World Wars are prime examples. And consider, too, in the recent past the agonising in the US over the Vietnam War, and the growing consensus around the 'foreign policy disaster' that was the Iraq War. The ambiguities around the role of war in the US are clear enough, and we see similar processes at work in Europe, with the attempts to create a usable past around the First World War on the occasion of the centenary since 2014. The relationship between war and nationalism is a contested, often unpredictable one, and the memory of violence can refract in dangerous ways. ${ }^{5}$

All that said, the ways in which history, and particularly histories of violent conflict, is a dichotomised realm in Africa is particularly stark. When we consider Africa from a Western military historical perspective, it might be argued that European war in the deeper past has long been the subject of celebration and commemoration, and has been the focus of scholarly literature of marked range and depth; such cultures of commemoration are fundamentally centred on the idea of the putatively transformative power of war itself, and certainly in the forging of national identities. Europeans share common cultures of memory and commemoration, even if they don't always agree on the details of cause and effect. The contrast, in terms of the historical relationship between war and nation, between Africa and the West is striking. In Europe and North America, long histories of violent contest gave rise to sites and dates of mourning and celebration which became part of the essential equipment of

\footnotetext{
${ }^{3}$ Igor Kopytoff (ed.), The African Frontier: the reproduction of traditional African societies (Bloomington \& Indianapolis, 1987), especially Kopytoff's own introduction.

${ }^{4}$ T.O.Ranger, 'Towards a Usable African Past', in Christopher Fyfe (ed.), African Studies since 1945: a tribute to Basil Davidson (London, 1976).

${ }^{5}$ John A. Hall \& Sinisa Malesevic (eds.), Nationalism and War (Cambridge, 2013).
} 
consolidated nationhood. ${ }^{6}$ And this is evident in the realms of popular military history, too: notably the work of military historians who return timelessly to Napoleon, Agincourt, Marlborough, Waterloo, Westphalia, Stalingrad, and who are keen always to reiterate those time-worn topics. ${ }^{7}$ But in Africa, the military inheritance is all the more problematic, and so much more disconnected from the putatively 'modern' - although attempts at such connections were indeed made.

\section{Mobilising The Precolonial}

The late precolonial era, including the transformative nineteenth century, was in many respects an era of remarkable political and military achievement - tantamount to a military revolution across a swathe of sub-Saharan Africa. ${ }^{8}$ The transformative nature of the era itself presented a dilemma to late colonial nationalists, who were therefore not able to draw on authentic 'traditions' from the nineteenth century; the armed polities of the era, as Hodgkin observed, "were in many cases either the products of revolutionary upheavals or attempting to carry out politics of internal reform and modernization". ${ }^{9}$ The irony lay in the fact that the nineteenth century was replete with warriors of global stature - if not of global fame - as builders of new states and reformers of old ones; it was an era in which the scale and objectives of warfare expanded considerably, involving new weaponry, and new methods of command and organisation. The military revolution, driven by a markedly dynamic armed entrepreneurialism, underpinned a parallel expansion of political scale and reach. In the economic sphere, these new polities deployed violence as a means to economic growth, the expansion of commercial operations, and the ever-more efficient mobilisation of factor endowments: people, metals, animals, textiles, soil. Africa's nineteenth-century military transformation could be conceived of as laying the groundwork for political modernity, in much the same way as Europe's own putative military revolution between the sixteenth and the eighteenth centuries created the conditions for modern state-formation and the construction of nations with those state structures at their centres. ${ }^{10}$

For our purposes, Uganda exemplifies these broader trends. Within the territory of the modern republic, the era between the fifteenth and the eighteenth centuries was the epoch of the warrior-king, associated with salvation and reconstruction. ${ }^{11}$ Rich oral traditions, first recorded

\footnotetext{
${ }^{6}$ Notably, see Jay Winter, Sites of Memory, Sites of Mourning: the Great War in European cultural history (Cambridge, 1995). For a compelling account of histories of national catastrophe drawing on the examples of the American South after 1865, France after 1871, and Germany after 1918, see Wolfgang Schivelbusch, The Culture of Defeat: on national trauma, mourning, and recovery (London, 2003).

${ }^{7}$ I am thinking here of Anthony Beevor, Andrew Roberts, and numerous others.

${ }^{8}$ For example Richard J. Reid, 'The Fragile Revolution: rethinking war and development in Africa's violent nineteenth century', in E.Akeampong, R.H.Bates, N.Nunn \& J.Robinson (eds.), Africa's Development in Historical Perspective (Cambridge, 2014). See also G.N.Uzoigwe, 'The warrior and the state in precolonial Africa', in A.A.Mazrui (ed.), The Warrior Tradition in Modern Africa (Leiden, 1977).

${ }^{9}$ Thomas Hodgkin, 'The relevance of "Western" ideas for the new African states', in J.Roland Pennock (ed.), Self-Government in Modernizing Nations (Englewood Cliffs, NJ, 1964), 66; also James Smoot Coleman, 'Tradition and Nationalism in Tropical Africa', in J.S.Coleman (ed. Richard L. Sklar), Nationalism and Development in Africa: selected essays (Berkeley, 1994).

${ }^{10}$ For useful summations of the European experience, see for example Michael Howard, War in European History (Oxford, 2002), 13-14; and more detailed examinations in Geoffrey Parker, The Military Revolution: military innovation and the rise of the West, 1500-1800 (Cambridge, 1988, 1996); also Tilly, Coercion. ${ }^{11}$ For example, R.Oliver, 'Discernible developments in the interior, c.1500-1840', in R.Oliver \& G.Mathew (eds.), History of East Africa Vol I (Oxford, 1963); J.-P.Chretien, The Great Lakes of Africa: two thousand years of history (New York, 2003). See also David Schoenbrun, 'Conjuring the Modern in Africa: durability and rupture in histories of public healing between the Great Lakes of East Africa', American Historical Review, 111:5 (2006).
} 
in the late nineteenth century, provided stories of military glory, dastardly rebellion, individual heroism, and the sagacity of founding fathers for several centuries before that. War was vital, indeed it was life itself, and was viewed in Manichaean terms: legitimate and righteous, evil and brutal, drawing out the extreme qualities in the human character - the cowardly, the heroic, the accomplished, the tragic, the richly rewarded, the bereft. In so many ways, war and the deployment of arms was posited as the purest form of human endeavour and leadership; heroes were celebrated, and transgressors used as moral indices for the individual as well as the wider community. Across the region - in kingdoms such as Buganda, Bunyoro, Nkore, and Toro political centralisation meant tightened political control of increasingly professional armies for the purpose of external defence and domestic solidity. ${ }^{12}$ The trend was clear enough among the forest kingdoms of southern Uganda, but it is in evidence, too, in the turbulent north: among the Acholi, and the Langi, and others, the momentum was toward the enlargement of political and military scale, the emergence of charismatic military leadership, and the consolidation of ever larger field forces underpinned by distinctive warrior identities and cultures of militarism. ${ }^{13}$ War, moreover, facilitated social mobility, as encapsulated in the story of a man named Kasindula, as told to the explorer Henry Morton Stanley in 1875. A humble local subchief of Buganda with little worldly wealth, Kasindula nonetheless brought himself to the attention of the mid-nineteenth century kabaka Suna by singlehandedly waging war on the Soga across the Nile and gathering more booty (an improbable amount of it) than any of the great chiefs, the men of privilege, at the royal court. He was duly rewarded with rank and riches, and in a stirring public address - doubtless embellished by the journalist Stanley - Suna pointedly contrasted his achievements with the inert privilege of his senior chiefs. ${ }^{14}$ War was politics, and politics war: as the king of Bunyoro explained to the explorer John Hanning Speke, "The brothers fought for [the throne], and the best man gained the crown." 15 The early twentieth-century Ganda author, the Rev. Bartolomayo Zimbe, agreed: "a Kingdom is always conquered, not succeeded to." 16

It was hardly surprising, then, that war was foremost in the minds of the first generation of Ugandan writers and historians who went into print in the 1900s and 1910s. Most of them had experienced the violent vicissitudes of the late nineteenth century, and - in the case of Sir Apolo Kagwa, most famously, prime minister of Buganda from 1889 to 1926 - had been protagonists in those upheavals. They had also inherited versions of those long-standing oral texts which commemorated and glorified violence as a means to individual and collective accomplishment. They wrote their histories with a view to building the new colonial society, and none doubted that violence had been at the centre of that process of remaking Uganda.

\footnotetext{
12 A.Kagwa (tr. \& ed. M.S.M.Kiwanuka), The Kings of Buganda (Nairobi, 1971), 124; Richard J. Reid, Political Power in Pre-Colonial Buganda: economy, society and warfare in the nineteenth century (Oxford, 2002); Henri Médard, La Royaume du Buganda au XIXe siècle (Paris, 2007). For Bunyoro, see John Nyakatura, (ed. G.N.Uzoigwe), Anatomy of an African Kingdom: a history of Bunyoro-Kitara (New York, 1973); Shane Doyle, Crisis and Decline in Bunyoro: population ad environment in western Uganda, 1860-1955 (Oxford, 2006). On Busoga: D.W.Cohen, The Historical Tradition of Busoga: Mukama and Kintu (Oxford, 1972); and for Toro and the western kingdoms, E.I.Steinhart, Conflict and Collaboration: the kingdoms of western Uganda, 1890-1907 (Princeton NJ, 1977).

${ }^{13}$ R.R.Atkinson, The Roots of Ethnicity: the origins of the Acholi of Uganda before 1800 (Philadelphia, 1994), 271-2; John Lamphear, 'The evolution of Ateker "New Model” Armies: Jie and Turkana', in K.Fukui \& J.Markakis (eds.), Ethnicity and Conflict in the Horn of Africa (London, 1994); J.C.D.Lawrance, The Iteso: fifty years of change in a Nilo-Hamitic Tribe of Uganda (London, 1957), 13-16.

${ }^{14}$ Stanley, Through the Dark Continent, I, 289-94.

${ }^{15}$ Speke, Journal, 547; see also Nyakatura, Anatomy, 100; John Roscoe, Twenty-Five Years in East Africa (Cambridge, 1921), 254; John Roscoe, The Bakitara or Banyoro (Cambridge, 1923), 314.

${ }^{16}$ B.M.Zimbe, 'Buganda ne Kabaka [Buganda and the King]', (unpublished ms., Makerere University Library, Kampala, c.1939), 83, 107.
} 
Thus were Kagwa's now-classic texts on Buganda's history and customs - inspired in no small measure by his reading of Holy Scripture in Luganda as a young convert, or musomi ('reader') at the royal court - replete with military narratives, details on great wars and specific campaigns, the character and behaviour of commanders, and the rise and fall of men based on their qualities in battle: here there were stories of hubris, over-ambition, guile, cowardice, raw courage, humility, loyalty. ${ }^{17}$ The importance of war and military culture is reflected, too, in the writings of Kagwa's close collaborator, the missionary John Roscoe, who clearly derived much of his information from Kagwa. ${ }^{18}$

By the 1930s, the generation which had 'managed' Buganda's transition to colonial modernity was going into print. Some - such as Samusoni Mazinga and the reigning king himself, Daudi Chwa - remembered the precolonial past in romantic hues, and depicted a pristine society of impeccable manners and remarkably little interpersonal violence. ${ }^{19}$ But for others, their advancing years was a time to recall the righteous religious wars of the late nineteenth century, when they had wrestled with the forces of darkness to rescue the kingdom from civil strife and usher in spiritual truth. Produced in the course of the 1930s and early 1940s, the war memoirs of Albert Lugolobi, Zimbe, James Miti, and Ham Mukasa - formerly Kagwa's secretary differed somewhat in the detail, but all shared a desire to describe the heroics of their generation in fighting monarchical tyranny in the name of Christian truth. ${ }^{20}$ In so doing, they served to remind a younger generation - distracted by Westernisation and the fripperies of modernity not to lose sight of their achievements in waging war on behalf of an increasingly forgetful kingdom. Their military recollections were infused with a powerful sense of nationalist sentiment. ${ }^{21}$ What they tended to omit, of course, was the violence inflicted by the AngloGanda armies on a range of neighbours - not least Bunyoro - in the course of the 1890s, wars of conquest which laid the parameters, and the contours, of the nation-to-be.

Early access to literacy and the printed word had meant that Ganda narratives of war had pioneered the genre, but where Kagwa had first trod, others followed. Y.K. Lubogo's history of Busoga, written between 1921 and 1938, may have reflected a desire to demonstrate that the Soga had been "a complete tribe for many generations now with firmly established boundaries", but its intricate narrative described the significance of inter-clan warfare as well as the struggle of communities to protect themselves from outside incursions in which martial heroes abound.22 Bunyoro, Buganda's old foe and close neighbour, was also by the 1930s producing counternarratives to the Ganda texts; but the form and thematic emphasis was much the same, with due attention paid to military trials and tribulations, glorious feats of arms, and the endeavours of great leaders of note - in the Nyoro case, those of the great warrior Kabalega. The reigning

\footnotetext{
${ }^{17}$ Kagwa's early writings - many of which were produced on his own printing press - include Basekabaka be Buganda - 'the Kings of Buganda' (1901); Empisa za Baganda, 'Customs of the Baganda' (1907); and Ebika bya Baganda (1912), 'Clans of the Baganda'.

${ }^{18}$ In Roscoe's The Baganda: an account of their native customs and beliefs (London, 1911), Chapter 10 is devoted to 'Warfare' which also appears intermittently throughout the lengthy tome. A useful overview of the relationship between the two men appears in J.Rowe, 'Roscoe's and Kagwa's Buganda', Journal of African History, 8:1 (1967).

19 J.Rowe, 'Myth, memoir and moral admonition: Luganda historical writing, 1893-1969', Uganda Journal, 33:1 (1969), 24-25; Kabaka Daudi Chwa, Education, Civilisation, and Foreignisation in Buganda (orig. published 1935), reproduced in D.A.Low (ed.), The Mind of Buganda: documents in the modern history of a kingdom (London, 1971), 104-8.

${ }^{20}$ Zimbe, 'Buganda'; Rowe, 'Myth', 24; James Miti, ‘A History of Buganda' (unpublished manuscript, SOAS Library, London, c.1938).

${ }^{21}$ Rowe, 'Myth', 24-5.

${ }^{22}$ Y.K.Lubogo, 'A History of Busoga' (translated \& unpublished manuscript in Makerere University Library, Kampala, 1960), 3.
} 
mukama or king of Bunyoro Tito Winyi (1924-1967) wrote a set of articles under a pseudonym in the mid-1930s in the Uganda Journal in which he highlighted Nyoro's own claims to be the great military power of the region's recent past, ${ }^{23}$ while John Nyakatura's extended text was likewise heavily martial in content and indeed, in some respects, purpose. ${ }^{24}$ Armed endeavour was prominent, too, in Lazaro Kamugungunu and A.G.Katate's history of the kings of Ankole, written once more in the style of Kagwa and Nyakatura. ${ }^{25}$ In each case, the text reflected unambiguously and unashamedly the importance of martial prowess to 'traditional' leadership, and to political and cultural identity. War, the authors were saying in each text, had made the kingdom. Perhaps, too, there was - at least in the case of Bunyoro and Ankole, but conceivably also in the case of Buganda - an element of wistful nostalgia for an age in which the agency of political change and social progress had been the man-at-arms; some primordial yearning for an epoch which must have seemed heroic to a generation of bureaucrats in colonial employment, as Nyakatura, Katate, Kamugungunu, and ultimately Kagwa himself - survivor of late-nineteenth-century traumas though he was - had all been.

Nationalists coming after the Kagwa generation at first followed suit. It seemed that the precolonial remained fertile ground and that it provided the kinds of heroes who could be relied upon to support nationalist struggle. In Tanzania, the Tanganyika African National Union (TANU) of the 1950s at first embraced continuity and demonstrated a self-conscious desire to historicise the African struggle. In this case, the relevant hero was a remarkable figure named Mirambo, who led a veritable military revolution among the Nyamwezi people of central northern Tanzania between the 1860s and the 1880s. He embodied the nineteenth-century transformation of warfare in Africa more broadly, with his energetic reform and leadership, his reorganisation of the practice and culture of war, his creation of a wholly new - if short-lived - polity. Famed for his military innovations, and his domination of coast-bound trade routes which linked the region to the global economy, ${ }^{26}$ Mirambo looked to the nationalists of the 1950s like a ferocious defender of African sovereignty and a champion for their times. President Julius Nyerere stuck to broad themes in his opening address to the famous meeting of Africanist historians in Dar es Salaam in $1965,{ }^{27}$ but the nineteenth century loomed large in TANU's historical imagination. This ostensibly most progressive of nationalist movements adapted a song regularly performed by Mirambo's victorious soldiers as they returned from a successful campaign - Ohoo! Chuma chabela mitwe [Oh! Iron has broken heads] - to Ohoo! TANU yajenga chi; or 'Oh! TANU builds the country'. As local oral historian J.B. Kabeya explained:

It has become like the second National Anthem...[Nyerere], at a meeting of the TANU Youth League held in Tabora in 1962, said that this old battlesong should have new words to be sung in the building of our nation...Immediately the people took this up and since then this song has spread like wildfire all over Tanzania. These two great

\footnotetext{
23 'The Kings of Bunyoro-Kitara', Uganda Journal, 3:2 (1935); 'The Kings of Bunyoro-Kitara Part II' and 'Part III', Uganda Journal, 4:1 (1936) and 5:2 (1937) respectively.

${ }^{24}$ Nyakatura, Anatomy. This was first published as Abakama ba Bunyoro in 1947.

${ }^{25}$ Abagabe b'Ankole ('The Kings of Ankole') (Kampala, 1955); much of this material was translated into English and included in H.F.Morris, The Heroic Recitations of the Bahima of Ankole (Oxford, 1964).

${ }^{26}$ N.R. Bennett, Mirambo of Tanzania, 1840-1884 (New York, 1971). For contemporary accounts, see P. Broyon-Mirambo, 'Description of Unyamwesi, the territory of King Mirambo, and the best route thither from the East Coast', Proceedings of the Royal Geographical Society, 22:1 (1877-78); London Missionary Society Archives (SOAS Special Collections), Central Africa, Incoming, Box 3: Southon to Thomson, 28 March 1880, encl. 'History, Country, and People of Unyamwezi'.

${ }^{27}$ See 'Speech by the President of Tanzania, Mwalimu Julius Nyerere', in T.O.Ranger (ed.), Emerging Themes of African History (Nairobi, 1968).
} 
leaders, King Mirambo and Mwalimu Nyerere, are far apart in time. But they are both of one mind. They both wanted to build one nation and to make the country peaceful. A street was named after this "hero of Unyamwezi and the whole of Tanzania" in Dar es Salaam. ${ }^{28}$

For others, indeed, there were tangible lineages between Africans' violent resistance to European imperialism in the late nineteenth and early twentieth centuries, and the 'modern' nationalist movements of later years. ${ }^{29}$ In Tanzania, again, TANU appealed directly to the spirit of the Maji Maji rebellion against German rule in 1905-7, self-consciously mobilising ideas around radical nationalism and awarding these deeper historical roots: according to a nationalist newsletter in 1967, "On the ashes of Maji-Maji our new nation was founded." 30 Similarly, Zimbabwean nationalists in the late 1950s and early 1960s evoked the spirit of the 'first Chimurenga' - the uprising against European settlers by Ndebele and Shona peoples in 1896-97 - in mobilising resistance against the white minority regime in Southern Rhodesia. ${ }^{31}$ Later, in the 1980s and 1990s, Eritrean nationalists likewise occasionally sought to deepen the historical roots of their armed struggle by pointing to centuries of violent subjugation by 'Ethiopians' and long histories of resistance to that subjugation. ${ }^{32}$ Even the rapid emergence of army officers as leaders of the postcolony - the recurrent theme of African politics in the 1960s and 1970s - and the prevalence of the coup d'etat was, some proposed, emblematic of a much older pattern in the African body politic: as Ali Mazrui argued in the 1970s, perhaps Amin represented the 'Re-Africanization' of Africa, and was the manifestation of deeper, older forces at work in the postcolony. ${ }^{33}$ Certainly, there is an argument to be made about the extent to which Amin was symptomatic of the nineteenth-century militarisation of political culture, and its renaissance in the middle decades of the twentieth. ${ }^{34}$

So, too, arguably, was the emergence of revolutionary guerrilla movements - such as the National Resistance Movement in Uganda - which could be seen as representative of a longstanding pattern of rupture and rebirth, in which the armed frontier was mobilised to march on the centre, reorganising violence in order to effect political and social change. Despite the NRM's ambivalence about the past - more on which below - a cursory glance into Uganda's precolonial history revealed at least some elements worthy of admiration, even if grudging. NRM leader and, from 1986, President of Uganda Yoweri Museveni approved of some of the more expansionist 'tribal' chiefs of the precolonial era:

Some of the chiefs in our past history, however, tried to consolidate their rule, but today the neo-traditionalists are actually divisive... The old kings... were expansionists ... [However] [t]he precolonial indigenous states were weak because they had not yet succeeded in uniting all the tribes and consolidating the resources in this region. Some had made more progress than others, but they had not yet evolved enough power and

\footnotetext{
${ }^{28}$ J.B. Kabeya, King Mirambo: one of the heroes of Tanzania (Nairobi, 1976), ix-xi.

${ }^{29}$ T.O.Ranger, "Connexions between "Primary Resistance" movements and modern mass nationalism in East and Central Africa', Parts I \& II, Journal of African History, 9:3 \& 9:4 (1968).

${ }^{30}$ Quoted in Ranger, 'Connexions', Part II, 636.

${ }^{31}$ Ibid., 635-6.

${ }^{32}$ Roy Pateman, Eritrea: Even the Stones are Burning (Lawrenceville NJ, 1990, 1998), Chap 2; Semere Haile, 'Historical background to the Ethiopia-Eritrea conflict', in Lionel Cliffe \& Basil Davidson (eds.), The Long Struggle of Eritrean for Independence and Constructive Peace (Trenton NJ, 1988), 12-15; Jordan GebreMedhin, 'Eritrea (Mereb-Melash) and Yohannes IV of Abyssinia', Eritrean Studies Review, 3:2 (1999).

${ }^{33}$ Ali Mazrui, 'Soldiers as Traditionalizers: military rule and the reafricanisation of Africa', in Mazrui (ed.),

Warrior Tradition; for a slightly different approach, see also Ali Mazrui, 'The social origins of Ugandan presidents: from king to peasant warrior', Canadian Journal of African Studies, 8 (1974).

${ }^{34}$ I myself argue for this in my Warfare in African History (New York, 2012).
} 
unity to immunize themselves against foreign encroachment: that is why they were conquered. ${ }^{35}$

Wars of expansion were implicitly awarded the presidential seal of approval here - the violence of 'the old kings' was the means to an end, namely unity, and Museveni and the Movement, on this reading, were simply finishing the job.

Yet more than that, there was heroism to be mobilised and celebrated. Sometime in the early 1980s, Museveni - the student of revolutionary politics and sworn opponent of backward tribalism - was said to have visited, on at least one occasion, the shrine of the Ganda war god Kibuka to pay his 'respects' and perhaps to make sure all bases were covered in his campaign against incumbent Ugandan president Milton Obote. ${ }^{36}$ Around the same time, the National Resistance Army named two of its units 'Kabalega' and - a little more controversially, perhaps - 'Mwanga', "in honour", as Museveni himself described it, "of African heroic figures [who were] noted Ugandan opponents of British imperialism in the late $19^{\text {th }}$ century". ${ }^{37}$ These were the remarkable evocations of a national history at a time when the nation itself was being torn apart by the bloody violence of the second Obote regime. Museveni was clearly particularly fixated with Kabalega, the Nyoro king who was unambiguously a resister of foreign colonialism, as well as a gifted military reformer, and has long been recalled by the downtrodden and marginalised Nyoro as one of their great historical figures. ${ }^{38}$ In 2009 , Kabalega was declared a national hero, which entitled him to a medal and a 21-gun salute. ${ }^{39}$ Things were a little more problematic with respect to Mwanga, whose heroism, after all, was of a rather more ambivalent hue: he had actively worked with the British for several years before rebelling, briefly, in 1897, when he threw his lot in with Kabalega in resisting the consolidation of British rule. Somewhat more problematically, Mwanga was probably homosexual, which in the context of escalating homophobia in Uganda in recent years was probably more iniquitous than collaboration with the colonial power - although, for Museveni, Mwanga was flawed and susceptible rather than downright evil. ${ }^{40}$ Either way, there would be no gun salute for him, despite some scholarly revisionism. ${ }^{41}$

The NRM in Uganda was not the only revolutionary liberation front to select usable champions from the precolonial past. In South Africa, the Zulu 'warrior tradition' - ostensibly at least furnished the ANC with a model of armed resistance. At his trial in 1962, Nelson Mandela invoked the name of Dingane, Shaka's half-brother and Zulu king from 1828 to 1840, and the

\footnotetext{
35 'Political substance and political form', speech at the opening of a political seminar for National Resistance Council members, 6 September 1989, in Yoweri K. Museveni, What is Africa's Problem? (Minneapolis, 2000), 163-4.

${ }^{36}$ Author's field notes and informal interviews, Kampala, 6 August 2010. Kibuka was a warrior from the Sesse Islands on Lake Victoria whose help was recruited by the kabaka of Buganda during a particularly bruising war with Bunyoro, possibly in the sixteenth century. He was killed in the fighting, despite being able to fly, and at some point afterwards was elevated even higher to become the main lubaale or national spirit of Ganda warfare. ${ }^{37}$ Museveni, Mustard Seed, 137.

${ }^{38}$ John Beattie, The Nyoro State (Oxford, 1971), 31-2, 58; Harold Ingrams, Uganda: a crisis of nationhood (London, 1960), 241-2; and more recently, 'Kabalega: the symbol of colonial resistance', NV, 9 January 2012. 39 'Kabalega named national hero', New Vision (Kampala), 10 June 2009; author's field notes and informal interviews, Kampala, 16 August 2012. For rather more sceptical interpretation, based on the President's need for Nyoro political support and economic co-operation, see 'Gen. Museveni woos Banyoro with medals', The Observer (Kampala), 16 June 2009.

${ }^{40}$ See for example 'Uganda's president admits gays part of Africa's heritage, Changing Attitude, 3 April 2012; R.Rao, 'Re-membering Mwanga: same-sex intimacy, memory, and belonging in postcolonial Uganda', Journal of Eastern African Studies, 9:1 (2015).

${ }^{41}$ Samwiri Lwanga Lunyiigo, Mwanga II: resistance to imposition of British colonial rule in Buganda, 18841899 (Kampala, 2011).
} 
Zulu uprising of 1906-8, as the progenitors of the heroic struggle of which the ANC and others were now a part. He also made reference to the resistance offered against white expansion by his own ethnic group, the Xhosa. ${ }^{42}$ Mandela later recalled that date chosen in 1961 for the launch of the armed wing of the ANC, Umkhonto we Sizwe ('Spear of the Nation') - 16 December - was 'Dingane's Day'. "That day", wrote Mandela, "white South Africans celebrate the defeat of the great Zulu leader Dingane as the Battle of Blood River in 1838...We chose 16 December to show that the African had only begun to fight, and that we had righteousness - and dynamite - on our side."43 Yet such invocations were not unproblematic. By the 1980s, ideas about the Zulu military tradition were serving to fuel a distinctive Zulu nationalism in Natal which was pitted against all outsiders and non-Zulu speakers - including the ANC and its supporters. ${ }^{44}$ Shaka himself might exemplify a heroic black militarism and tradition of resistance; but he was a divisive, contested figure, and there was no unified vision - or even ownership - of him among black South Africans. ${ }^{45}$

What is clear from the foregoing is that particular historical figures, and the circumstances within which they supposedly operated, served the purposes of nationalist struggle, whether violent or otherwise. Various actors - including the leaders of movements, and their supporters - were able to draw lines of descent from precolonial warfare to their own political projects. Yet this historicity needs to be set alongside an equally evident discomfiture with the violent past, and the ways in which an increasingly radical politics had little time for the heroes of precolonial yore. The nationalist movements which emerged across Africa from the 1960s onward increasingly wrestled with war in the deep past, and with the acquisition of usable warrior heroes from the precolonial era.

\section{The Blinding Violence of the Present}

The utilisation of the deeper past was a complicated business. In general terms 'nationalism' in Africa was seen as the product of modernity, of socio-political change induced by colonial rule, change which political leaders sought to harness and mobilise in the pursuit of narrowdefined provincial, ethnic, or religious agendas. ${ }^{46}$ And of course most - if indeed not all African nationalists thought in terms of those sectional or regional interests: the modern 'tribalism' which was such a focus for political scientists, historians and anthropologists in the

\footnotetext{
${ }^{42}$ Carl F. Hallencreutz, 'Thomas Mofolo and Nelson Mandela on King Shaka and Dingane', in Raoul Granqvist (ed.), Culture in Africa: an appeal for pluralism (Uppsala, 1993), 185.

${ }^{43}$ Nelson Mandela, Long Walk to Freedom (London, 1995), 274-5.

${ }^{44}$ Carolyn Hamilton, Terrific Majesty: the powers of Shaka Zulu and the limits of historical invention (Cape Town and Johannesburg, 1998), 202-3.

${ }^{45}$ See for example Daphna Golan, Inventing Shaka: using history in the construction of Zulu nationalism (Boulder CO, 1994); Dan Wylie, Myth of Iron: Shaka in History (Scottsville, 2006). Of course Shaka was one of those characters who transcended national boundaries. A Ugandan informant, asked to reflect on the significance of the precolonial past, enthused not about a figure from Uganda's history, but about how he was inspired by "the history of... past great people and their contributions to the communities that they came from e.g. Shaka Zulu in South Africa among the Zulu people; hence the spirit of fighting and protection of your people that may be oppressed and exploited by superior groups." Indeed, the same informant was inspired by "the philosopher of nationalism and patriotism like Nyungu ya Mawe among the Ndebele" [sic], and more generally there was succour from the deeper past in terms of "how societies protected themselves from external aggressors", which was a central motif for this particular interviewee: Interview with Khaukha Musungu Paul, Bubutu, Uganda, January 2014.

${ }^{46}$ John Lonsdale, 'Some origins of nationalism in East Africa', Journal of African History, 9:1 (1968); Basil Davidson, Which Way Africa? The search for a new society (Harmondsworth, 1964).
} 
1960s. ${ }^{47}$ The pioneering scholar of African nationalism, and a contemporary observer of it, Thomas Hodgkin, pointed out in the mid-1950s that "African nationalists have been compelled to develop their own counterattack; to answer the myth of African barbarism and backwardness with the counter-myth of African civilisation and achievement." ${ }^{48}$ Leaving aside the unfortunate implied scepticism that Africans might actually have access to anything like "civilisation and achievement", the argument remains of interest: which historic figures, particularly in the mould of great warrior, could nationalists refashion to their own ends? In Francophone West Africa, Malians might marshal the great fourteenth-century king Mansa Musa, ${ }^{49}$ and Mande-speakers could harness the epic of their folk-hero Sunjata. ${ }^{50}$ But in truth, while these characters might be repackaged as state-builders, ideologues, or political entrepreneurs, they were not always ideal vis-à-vis the needs of modern nationalists and the exigencies of modern nationalism. The latter wished to stress not histories of violence, but pacific achievement - in economy, technology, culture. ${ }^{51}$ Histories relating to war, militarism, force of arms, were generally regarded as negative stereotypes, redolent of missionary and colonial narratives of Africa's past in the late nineteenth and early twentieth centuries.

In Nyerere's Tanzania in the 1960s and 1970s, the Department of Antiquities neglected the upkeep of Mirambo's grave near Tabora: weeds grew up around the memorial, and the story of his heroics became consumed by the bush in the years after independence. ${ }^{52}$ In fact, as Kabeya noted, local ambivalence toward Mirambo could be traced back some years: "Even the colonial Government tried to place a memorial...on his grave, but evil-minded people went and broke it down and the District Council of Tabora has not up to this day paid any attention to this grave." ${ }_{53}$ The forgetting of the great Nyamwezi leader was emblematic of the ways in which histories of violence had begun to be troublesome to those with one eye on the enduring, nefarious idea of a Dark Continent crippled by mindless tribalism, and the other on the grand new vistas of African modernity. By the 1970s, Mirambo had come to represent the violent and traumatic upheaval of the precolonial era, and was of dubious utility to would-be nationbuilders and modernisers. Nor did it help that as much as anything else Mirambo was a slavedealer - one of the biggest in the East African interior - and that did not sit well with Nyerere's own romantic visions of a beatific African past, characterised as a communal idyll undisturbed by the ravages of industrial revolution. ${ }^{54}$ And as Kabeya conceded, "There are people who say that Mirambo was only a robber leader who attacked people on the roads and in the bush..." So much for the Mars of Africa, as Henry Morton Stanley - with perhaps just a touch of ironic hyperbole - had anointed him. ${ }^{55}$

In Uganda, meanwhile, the early twentieth-century authors discussed above were indeed keen on nineteenth-century history; but naturally they framed the late precolonial past in particular ways. War was prominent, clearly, and of ineffable significance. But in many respects it was seen as leading inexorably to peace and salvation, while at the same time they struggled with the meanings of the 'modern', and especially its meanings vis-à-vis the hardening

\footnotetext{
${ }^{47}$ P.H.Gulliver (ed.), Tradition and Transition in East Africa: studies of the tribal element in the modern era (London, 1969).

48 Thomas Hodgkin, Nationalism in Colonial Africa (London, 1956), 173.

${ }^{49}$ Ibid., 174.

${ }^{50}$ See for example 'Introduction' in Bamba Suso \& Banna Kanute (ed. Lucy Duran \& Graham Furniss), Sunjata (London, 1974, 1999).

${ }^{51}$ Hodgkin, Nationalism, 174.

52 Kabeya, King Mirambo, x.

${ }^{53}$ Ibid., $\mathrm{X}$-xi.

${ }^{54}$ Julius K. Nyerere, 'Ujamaa': The Basis of African Socialism (Dar es Salaam, 1962).

55 Stanley, Dark Continent, I, 384.
} 
conceptualisation of the nineteenth century as a murky, savage epoch which paved the way for enlightened civilisation. This was especially true of the generation that emerged in the 1930s and 1940s - the progeny of Kagwa and others - which was increasingly involved in what are broadly termed 'nationalist politics'. In Uganda, from the outset, the brittle nature of the nation meant that there could be no use for longue durée histories of war at the level of state-building. On the eve of independence, while the Ruwenzururu insurgency erupted in the far west, ${ }^{56}$ Buganda, the great martial power of the nineteenth century, was threatening to the derail the nation itself by threatening to secede. In 1966, in one of the first significant acts of political violence against the past in sovereign Uganda, Milton Obote sent troops against the Ganda royal enclosure, forcing the kabaka into exile; ${ }^{57}$ within months, the main kingdoms - Buganda, Bunyoro, Toro, Ankole, and Busoga - had been constitutionally abolished in what seemed like an act of violent revenge against the privileged southern states by a disgruntled northern politician, an echo of precolonial violence in what was a putatively modernist attempt to refashion the nation in unitary terms..$^{58}$

By the 1970s, the army was intervening in politics across the continent, a phenomenon which attracted much analysis at the time. ${ }^{59}$ The military coup d'etat was a typology of rupture exemplified by Idi Amin in Uganda, or Mengistu Haile Mariam in Ethiopia. These may well have been representative, as Ali Mazrui and others argued at the time, of precolonial dynamics: those of the 'Man on Horseback', the armed saviour, or even a reassertion of some timeless African masculinity briefly suppressed by the emasculation that was colonial rule. ${ }^{60}$ But these soldiers did not see themselves as the products, or the exponents, of some deeper culture of military involvement in the polity: they believed themselves to be emblematic of military modernity, the saviours of the nation, and professionals who could be entrusted with the task. ${ }^{61}$ Where civilians had failed, embroiled as they were in the tawdry business of ancient squabbles and pecuniary ambition, professional soldiers would hold steady the ship of state. In Ethiopia - perhaps more forcibly and dramatically than elsewhere - the forces of military modernity swept through the musty corridors, anterooms and myriad shadowed corners of the Imperial Palace when in 1974 the army moved against Haile Selassie. It was a story told in stark, if highly stylised, terms by Ryzsard Kapuscinski, whose tale of the Emperor's overthrow was one of how swiftly the past might be destroyed if ever there was one. ${ }^{62}$ The military command known as the Derg ('committee') - which led Ethiopia from the mid-1970s to 1991 espoused an aggressive, authoritarian Marxist-Leninism with all its modernist rhetoric and paraphernalia. The social and political transformation was embodied, too, in the emergence of the Derg's eventual leader, Mengistu Haile Mariam, for he was a professional soldier from the longmarginal Konso ethnic group in the southwest of Ethiopia, and probably of slave origins. The

\footnotetext{
${ }^{56}$ A.Syahuka-Muhindo, The Rwenzururu Movement and the Democratic Struggle (Centre for Basic Research, Kampala, 1991); Augustine Kyaminyawandi, The Faces of the Rwenzururu Movement (n.p., 2001). See also D.R.Peterson, 'States of Mind: Political History and the Rwenzururu Kingdom in Western Uganda', in D.R.Peterson \& G.Macola (eds.), Recasting the Past: history writing and political work in modern Africa (Athens OH, 2009).

${ }^{57}$ This is described in exactly these terms in The Kabaka of Buganda, The Desecration of My Kingdom (London, 1967).

${ }^{58}$ D.A. Low, Buganda in Modern History (London, 1971), 245-6; 'Address to the Nation by the President Dr. A. Milton Obote on the occasion of the sixth anniversary of independence on $9^{\text {th }}$ October 1968', Kabale District Archives COM18/CM157/Independence and Republic Celebrations and Labour Day.

${ }^{59}$ J.M. Lee, African Armies and Civil Order (London, 1969); W.F. Gutteridge, Military Regimes in Africa (London, 1975).

${ }^{60}$ See various contributions in Ali A. Mazrui (ed.), The Warrior Tradition in Modern Africa (Leiden, 1977).

${ }^{61}$ For example, Samuel Decalo, Coups and Army Rule in Africa: motivations and constraints (New Haven \& London, 1990), 33-8.

${ }^{62}$ Ryszard Kapuscinski, The Emperor: Downfall of an Autocrat (London, 2006; $1^{\text {st }}$ ed. 1978).
} 
modern army had facilitated his rise, and his displacement of a royal house which had stood for seven hundred years. ${ }^{63}$

Mengistu's counterpart in Uganda was Idi Amin, who dispatched Milton Obote into exile in 1971 and who consolidated the control of the army over Uganda for the next decade. Amin was a northerner - from the Kakwa, in the far northwest corner of the country - and indeed independent Uganda had its roots in the colonial-era creation of a north-south dichotomy: the centre of political gravity and economic 'development' was in the south, especially Buganda, while the north was a source of labour, including military labour. The north had long been the favoured hunting ground for recruits into the colonial army ${ }^{64}$ The image of the northern recruit is captured in Idi Amin's own early history, as the loyal NCO in the King's African Rifles hardly bursting with intelligence, but took orders well, and was a fine boxer; ${ }^{65}$ while the role of the soldier in Acholi society, another northern source of recruitment, is attested by the figure of the burly sergeant, apparently a veteran of the Second World War, in Okot p'Bitek's classic Luo-language novel Lak Tar, first published in 1953. ${ }^{66}$ Idi Amin's professional credentials were beyond question, as a former NCO in the King's African Rifles and then one of East Africa's first commissioned officers. Paradoxically, in some ways, it was his exposure to both British military modernity and to British military tradition which burnished him with that credibility. The sense of progress engendered by the British imperial mission further emphasised the striking disconnect between African past and African present. Yet Amin sought to present himself, too, as the vanquisher of the British, using war or the threat of it, and certainly the rhetoric of violence, to consolidate an idiosyncratic vision of the brittle nation. His expulsion of the Ugandan Asian community was the central plank in what he described as an 'economic war' ${ }^{67}$ He turned on its head his previous service in the KAR (he had fought Mau Mau rebels in Kenya) by promoting himself to Field Marshal with a splendiferous uniform to match, and designating himself 'Conqueror of the British Empire'. ${ }^{68}$

These regimes were soon to be challenged by a new phenomenon, the armed revolutionary front - and these identified themselves as the harbingers of a new social and political order which eschewed the failures of the past and emphasised the necessity of rebirth. In many ways this distinctive revolutionary historicism first emerged in Algeria. Frantz Fanon's exhortation to revolutionary anticolonial violence prompted a shift toward a more presentist, strikingly ahistorical culture of arms within which the role of war in Africa's deeper past was regarded with suspicion, even anxiety. His classic 1961 treatise - Les Damnés de la Terre, published in English as The Wretched of the Earth - quickly established an intellectual and moral framework within which a new generation of African political warriors could organise their

\footnotetext{
${ }^{63}$ For fascinating contemporary analysis, see Fred Halliday \& Maxine Molyneaux, The Ethiopian Revolution (London, 1981); and Peter Schwab, Ethiopia: Politics, Economics, and Society (London, 1985). See also Andargachew Tiruneh, The Ethiopian Revolution, 1974-1987: a transformation from an aristocratic to a totalitarian society (Cambridge, 1993).

${ }^{64}$ Gardner Thompson, Governing Uganda: British colonial rule and its legacy (Kampala, 2003), 104-5.

${ }^{65}$ For an eloquent examination of the imagery, see Mark Leopold, Inside West Nile: violence, history and representation on an African frontier (Oxford, 2005), 57-67. See also Henry Kyemba, State of Blood: the inside story of Idi Amin's reign of fear (London, 1977).

${ }^{66}$ It was later translated into English as White Teeth (Nairobi, 1989).

67 'Message to the Nation by His Excellency the President General Idi Amin Dada, on British citizens of Asian origin and citizens of India, Pakistan and Bangla Desh living in Uganda....12 ${ }^{\text {th }} / 13^{\text {th }}$ August, 1972', Speeches by His Excellency the President General Idi Amin Dada (Government Printer, Entebbe).

${ }^{68}$ For a selection of contemporary, often sensationalist, assessments, see T. Melady \& M. Melady, Idi Amin Dada: Hitler in Africa (Kansas City, 1977); D. Martin, General Amin (London, 1974); T. Donald, Confessions of Idi Amin (London, 1978); J.Kamau \& A.Cameron, Lust to Kill: the rise and fall of Idi Amin (London, 1979); M.L. Richardson, After Amin: the bloody pearl (Atlanta, 1980).
} 
armed struggles. ${ }^{69}$ Violence, he argued in the context of the Algerian Front de Liberation Nationale's struggle against France, was necessary: not only to utterly purge the insidious and pervasive influences of European colonial rule, but to address the psychological disorders which had arisen in the African mind as a result of foreign domination. Only violent struggle could truly liberate Africa; it would lay the groundwork for new nations, and point the way to socialist futures which were, after all, the only futures worth contemplating. By sheer force of arms would Africans eschew the awful past and march into postcolonial modernity. Fanon himself, of course, is the subject of a veritable canon of literature which has sought to clarify his meanings and intents, and at least some of which suggests that he was not actually exhorting Africans to violence. ${ }^{70}$ But that is how he was read and received by a generation of activists and nationalists across the continent - a generation born in the 1940s, which clutched copies of Wretched of the Earth to its breast at school and at university and ultimately in 'the bush', where he was taken into battle in pursuit of the new nation, and in flight from the evil past. In the late 1960s, Yoweri Museveni carried Fanon into the FRELIMO-liberated areas of northern Mozambique, and believed he had seen Fanon's theory of revolutionary violence 'verified'. ${ }^{71}$ Fanon created the conceptual baseline for liberation movements and provided the legitimacy for revolutionary violence - a kind of purification through fire of the political kingdom. Selfconsciously modernising revolutionary movements sought to build nations as entities of the (socialist) future, rather than as things of the past; they would be arenas of political modernity.

Few mid-twentieth century movements were able to tap into, or reinvent, the kind of nationalist history of anticolonial violence available in Algeria, for example: here, importantly, there were the benefits of Arabic literacy and literary culture, as well as the 'advantage' of long-term resistance to foreign invasion which could be moulded to serve contemporary needs. ${ }^{72}$ Yet Algeria and Fanon served to inspire new kinds of political movements and ultimately new ideas about the utilisation of violence across the continent, whether consciously or otherwise. These movements, with their roots in the political turbulence and excitement of the 1960s, espoused revolutionary violence and aimed at the salvation - nothing less - of the postcolonial nation. Revolutionary people's war, in other words, was at least implicitly dehistoricising and evangelical, and would bring about much-needed rupture between dark past and bright future. In Ethiopia, Eritrea, Zimbabwe, Mozambique, South Sudan, Rwanda and Uganda, there emerged movements which - though each distinct in specific objectives and local exigencies espoused a form of violent political rebirth: armed liberation fronts organised around the need for fundamental social revolution through warfare..$^{73}$ Of course, as we have already noted in some cases, these kinds of movements did sometimes seek to connect with the deeper past. But at the same time they espoused, and aspired to, a self-consciously modernist patriotism, and increasingly expressed an ambivalence about History as a discipline, and the past in general. Revolutionaries might occasionally make forays into military history in order to make a contemporary point; but revolution itself was not served by retrievals of the deep past. These movements advocated gender equality, land reform, education for 'the masses' and in particular the awakening and politicisation of slumbering peasantries. Histories of war in the deep past were largely irrelevant, and the only history that really mattered was the recent past

\footnotetext{
${ }^{69}$ Frantz Fanon (tr. Constance Farrington), The Wretched of the Earth (London, 1967, 1990). See also Toward the African Revolution (New York, 1964, 1967).

${ }^{70}$ See for example Anthony C. Alessandrini (ed.), Frantz Fanon: Critical Perspectives (London, 1999).

${ }^{71}$ Yoweri Museveni, 'Fanon's theory on violence: its verification in liberated Mozambique', in

N.M.Shamuyarira (ed.), Studies in Political Science, 3 (Dar es Salaam, 1974); Pascal Ngoga, 'Uganda: the National Resistance Army', in C. Clapham (ed.), African Guerrillas (Oxford, 1998), 92. See also Yoweri

Museveni, Sowing the Mustard Seed: the struggle for freedom and democracy in Uganda (Oxford, 1997), 24-5.

72 James McDougall, History and the Culture of Nationalism in Algeria (Cambridge, 2006).

${ }^{73}$ See for example Christopher Clapham (ed.), African Guerrillas (Oxford, 1998).
} 
of political oppression and violent marginalisation at the hands of occupying regimes or internal tyrannies.

One of the starkest cases is Eritrea, where the Eritrean People's Liberation Front (EPLF) waged one of Africa's longest wars, for independence from Ethiopia, from the early 1970s until 1991. While a handful of activists sought to claim continuity for the armed struggle from the deeper past, as noted earlier, the EPLF itself was scarcely interested in anything much before the 1950s, although of course Italian colonial rule (c.1890-1941) putatively provided a legal basis for independent statehood. The EPLF's objective was a socialist revolution, to be achieved through the blood sacrifice of its fighters. ${ }^{74}$ In developing its political programme, ${ }^{75}$ the Front sought a modernist, revolutionary antidote to the oppressive antiquity of its neighbour (and occupier) Ethiopia. After achieving independence in 1991, the EPLF reified the public memory of the armed struggle and the resultant sacrifice on which the nation was built, notably through the use of national days of mourning (Martyrs' Day, 20 June) and commemoration (Independence Day, 24 May). ${ }^{76}$ A similar culture of memorialisation was evident in Rwanda, where the horrors of the 1994 genocide - and the salvation of the nation by the Rwandan Patriotic Front - bore witness to catastrophic deeper histories of tribalism and division. Those histories needed careful managing as a result, and quarantined or even banned altogether. ${ }^{77}$

A process of historical quarantine was also at work in Ethiopia, though here the situation was complicated by the long recorded history of which Ethiopians - or some of them, at least were justly proud. The Tigray People's Liberation Front (TPLF) was able, to some extent, to draw on the memory of the last Tigrayan emperor, Yohannes IV (1872-1889); ${ }^{\cdot 7}$ but as the vanguard movement in the Ethiopian People's Revolutionary Democratic Front (EPRDF), a coalition of liberation movements ranged against the Derg, the TPLF was increasingly ambivalent about Ethiopia's deeper past. Tragic heroes such as Emperor Tewodros - caught in the pre-dawn between savage primitivism and modernising reform, and who committed suicide in the face of British invasion in 1868 - might continue to haunt the Ethiopian imaginary. ${ }^{79}$ And of course the battle of Adwa in 1896 gave rise to one of the most important annual national days in the calendar, 2 March, commemorating the moment when Ethiopia successfully defeated an invading Italian army, thus preserving its independence at the height of the European scramble for Africa. ${ }^{80}$ But even Adwa Day, while inviolable as a public holiday, was not unproblematic to those ethnic groups - Tigrayans and Oromo, most obviously - who felt a little uneasy about lauding the Amhara emperor, Menelik, who had won the battle itself, for Menelik was also the creator of an imperial hegemony which oppressed many nonAmhara. The Tigrayan-led EPRDF, in power from 1991, sought to neutralise the violent past

\footnotetext{
${ }^{74}$ Dan Connell, Against All Odds: a chronicle of the Eritrean Revolution (Lawrenceville NJ, 1997).

75 'National Democratic Programme, Eritrean People's Liberation Front, March 1987', in Cliffe \& Davidson (eds.), Long Struggle, 207-8.

${ }^{76}$ Author's field notes and informal interviews, Eritrea, 1997-2008. See also Richard Reid, 'Writing Eritrea:

history and representation in a bad neighbourhood', History in Africa, 41 (2014).

${ }^{77}$ Richard Reid, 'States of Anxiety: history and nation in modern Africa', Past and Present, 229 (2015), $256-7$.

Warnings of the dangers of history have been incorporated into the very constitution of Rwanda, revised on 26

May 2003: see http://www.rwandahope.com/constitution.pdf.

78 John Young, Peasant Revolution in Ethiopia: the Tigray People's Liberation Front, 1975-1991 (Cambridge, 1997), 94, 99.

${ }^{79}$ Taye Assefa, 'Tewodros in Ethiopian historical fiction', Journal of Ethiopian Studies, 16 (1983).

${ }^{80}$ See for example Paulos Milkias \& Getachew Metaferia (eds.), The Battle of Adwa: Reflections on Ethiopia's Historic Victory Against European Colonialism (New York, 2005).
} 
and detach the age of kings and their wars from the brave new world of social development and economic growth. ${ }^{81}$

Uganda further elucidates the paradox and ambiguity which often attended the memory and mobilisation of violent conflict in pursuit of national identity, and of national history; the rejection of the idea that historical violence had had any meaningful utility, and, despite the NRM's own immediate history, the embracing of normative modern ideas about violence as inimical to 'development'. Come the NRM, come another new beginning; except this one, said Museveni, was for real. This new beginning really was the Rupture from the Past to end all Ruptures; their war, indeed, was the war to end all wars. And so, for all the grudging respect to those expansionist precolonial chiefs noted earlier, Museveni was doggedly, at least publicly, Anti-History. During the public discourse on history during the jubilee celebrations celebrating Uganda's fiftieth birthday as an independent state in 2012, the deeper past, whether represented by personality or by process, was conspicuous by its absence - notwithstanding a handful of exceptions, such as Nyoro king Kabalega. The cause of so much apparent amnesia was violence, or more precisely the perception that the past was rather too full of it, or at least the kind that had gotten Africa precisely nowhere. Museveni offered his own interpretation of those histories in a speech at a political seminar in 1989:

Before colonial rule, we had backward tribal states here. If anyone tries to glamorise them, he is telling you a lie. If these tribal entities were equal to the tasks of a viable nation-state, why did they surrender their sovereignty to foreigners? Can any foreigner come here now and take away our sovereignty? It is impossible! This is because our present state is superior to the ancient tribal ones. ${ }^{82}$

Ultimately, the nation is defined as a thing of modernity, while the deeper past is characterised by savage tribalism and internecine warfare - there could be no 'Uganda' there. ${ }^{83}$ Movements such as the NRM needed to be highly selective in their approach to war in the deeper past - a process of foreshortening, indeed - in order to consolidate the nation, which was not served by histories of violence in the precolonial era.

All nations need wars for internal consumption; they require heroes, and martyrs, in order to legitimise incumbent regimes. But those wars, and their fallen, tended to be of more recent vintage. In Uganda, the reluctance to endow too many precolonial processes with constructive significance in the context of war and militarism contrasts sharply with the government's willingness to acknowledge the talent and patriotism of two very recent adversaries, General Tito Okello Lutwa, Museveni's immediate predecessor, and General Oyite Ojok, Obote's army chief staff in the early 1980s. Ojok was declared a national hero in 2010, and was awarded due respect as an honourable and worthy foe in the panoply of historic patriots during the 2012 jubilee celebrations. ${ }^{84}$ Tito Okello's record in power (July 1985-January 1986) was regarded as a mixed bag: a professional soldier, he was remembered alternately as a man with some "good ideas" but with little time to implement them, as bringing some economic stability to Uganda, and as presiding over violent political instability and widespread extrajudicial killing. Nonetheless, in 2010, Museveni posthumously awarded him the Kagera National Medal of

\footnotetext{
${ }^{81}$ Author's field notes and informal interviews, Addis Ababa, 2005-2014; Izabela Orlowska, 'Forging a nation: the Ethiopian millennium celebration and the multi-ethnic state', Nations and Nationalism, 19:2 (2013).

82 'Political substance and political form', speech at the opening of a political seminar for National Resistance Council members, 6 September 1989, in Museveni, What is Africa's Problem?, 163-4.

${ }^{83}$ Author's field notes and informal interviews, Uganda, 2010-2015; also Richard J. Reid, 'Ghosts in the Academy: historians and historical consciousness in the making of modern Uganda', Comparative Studies in Society and History, 56:2 (2014).

84 'Oyike Ojok, one of Uganda's best soldiers', New Vision (Kampala), 7 February 2012.
} 
Honour for his role in fighting Amin in the 1970s. ${ }^{85}$ Their efforts were, at least, somehow patriotic, and legitimate, if wrongheaded.

An entirely different interpretation was offered of the war in the north. The military rupture engendered by the NRA's seizure of power in 1986 was followed by Museveni's men ravaging and pillaging north of the Nile in what was in effect punishment for northern tyranny and militarism; it was awful brutality which itself gave rise to local resistance, in the form, first, of the Holy Spirit Movement under the prophetess Alice Lakwena, and then the Lord's Resistance Army (LRA) under her erstwhile lieutenant Joseph Kony. The terrible war in the north which resulted enabled the NRM to militarise and in effect further marginalise the north as a troublesome frontier zone, where wayward and backward people had brought dreadful violence on themselves; northern Uganda became a place where the UPDF - its inability to actually defeat the LRA or capture Kony notwithstanding - could demonstrate military prowess, and the government could, through repeatedly reheated but largely ineffectual 'development' schemes, demonstrate its political benevolence. ${ }^{86}$ It was a bitter irony indeed for a swathe of territory which served as a useful badland to a government desirous of maintaining a degree of militarisation, and a head of state who still liked to periodically don the khakis. For the same reason, the neglected and fly-blown district of Karamoja in the far northeast corner of Uganda - another place where desperate herdsmen toted AK-47s in apparent defiance of modernity and civility - had its own dedicated government minister, for a time none other than the President's own wife, Janet Museveni. All nations have cores and peripheries, centres and margins. And it is in those borderlands that a military regime such as the NRM demonstrates its power and its prowess; the 'Otherisation' of troublesome people in turbulent peripheries has long enabled regimes to achieve justification and set up the juxtaposition of internal legitimacy versus the chaotic brutality of the badlands. The latter are also critical externally, for peripheries can be useful buffers and militarised zones, platforms for external adventurism and the armed entrepreneurialism on which the region's political culture is largely based. Uganda is the product of a complex network of military frontiers and rough edges. Those frontiers operate in much the same way as they always have: facilitating armed creativity, facilitating essentialised senses of 'self' for all involved, and permitting hegemonic regimes to project benevolence and to develop security agendas. More recently, Museveni has directed military adventurism outward, with war becoming an increasingly central part of Ugandan foreign policy across the region. ${ }^{87}$ The Movement has used regional threats to strengthen its internal security agenda, while positioning Uganda as a pivot of global security. Museveni has to date given no indication that he believes any of these wars might be to Ugandans what the Trojan War was (according to Thucydides) to the Greeks: the unity in armed purpose of formerly disparate tribes. ${ }^{88}$ So far, external adventures have had, if anything, the opposite effect; but, in any case, Uganda's militarised foreign policy is in keeping with a nation whose deep roots are in war.

\footnotetext{
${ }^{85}$ See for example 'Tito Okello: the president who was kept on his toes', New Vision, 25 January 2012.

${ }^{86}$ By Human Rights Watch, see The scars of death: children abducted by the Lord's Resistance Army in Uganda (New York, 1997); Abducted and Abused: renewed conflict in northern Uganda (New York, 2003); Uprooted and Forgotten: impunity and human rights abuses in northern Uganda (New York, 2005). See also T.Allen \& K.Vlassenroot (eds.), The LRA: myth and reality (London, 2010).

${ }^{87}$ Filip Reyntjens, The Great African War: Congo and regional geopolitics, 1996-2006 (Cambridge, 2009); International Crisis Group, South Sudan: keeping faith with the IGAD peace process, Africa Report No.228, 27 July 2015.

${ }^{88}$ The Rev. Henry Dale, The History of the Peloponnesian War (London, 1849), 2-3; Samuel, 'Epical History', 6.
} 


\section{CONCLUSIONS: \\ War, History, AND The Political Kingdom}

In the West, oftentimes, the relationship between recent war and nation-building is more significant than anything the deeper past has to offer. No doubt, Raphael Samuel had a powerful point when he thoughtfully tackled the relationship between nation and military memory, memorably observing:

The disasters of the Gallipoli campaign, by common consent, marked Australia's coming-of-age; are we to say less of the battle of Thermopylae...? By what right do we claim the Maginot line...for the history of modern nationalism, while leaving the fortifications of Anatolia...to the archaeologists? ${ }^{89}$

Hobsbawm was more sceptical. ${ }^{90}$ But there is no doubt that, in much of sub-Saharan Africa from the mid-twentieth century onward, political fragility rendered the deeper past an unhealthy environment indeed. This was true even in Ethiopia, a modern nation which boasts an unusually richly recorded past but where the EPRDF is uneasy about the ascription of glorious military victories to an ancien regime rooted in ethnic imperialism. According to Charles Tilly in the European context, states made war, and war made states, and by extension, nations. ${ }^{91}$ Not so in Africa, or at least not in quite such linear terms. As René Lemarchand has demonstrated for Central Africa, nationalism has not been a unifying force when mobilised for war, but rather the opposite, exacerbating deep fissures between ethnic and cultural communities, and in some cases leading to some of the worst violence on the planet since the end of the Cold War. ${ }^{92}$ War, according to most analyses over the last half-century or so, has been at the very least inimical to national cohesion and construction, to the consolidation of the postcolonial political order so necessary to achieve broadly-defined socio-economic 'development'.$^{93}$ It has even been the destroyer of all those things held dearest in the modern humanitarian lexicon, and in many ways this anxiety, or at least uneasy ambivalence, has been extrapolated backwards into the deeper past.

Visions of violence danced before the eyes of would-be nation-builders, who were haunted by the ghastly spectacle of bloodthirsty despots and implacable tribes, tropes beloved of colonial officials. Imperial partition cast long shadows, but produced short memories; at the same time, the evangelical spell created visions of a past that was damned, and Christianity distorted ideas about how time worked, cursed history, led to new emphases on rupture and rebirth. How to use (or not use) these turbulent, creative histories in the modern era? Just as people built places to belong to, so they built time to which to belong, too. As the twentieth century drew on, there emerged a different attitude to those martial pasts: at best, one of uneasy ambivalence, among those who wrestled with cultural pride in 'traditional history' on the one hand and with the

\footnotetext{
89 'Epical History: the idea of nation', in Island Stories: Unravelling Britain. Theatres of Memory, Vol II (London \& New York, 1998), 8.

${ }^{90}$ Eric Hobsbawm, On History (London, 1997), 6-7.

${ }^{91}$ C. Tilly, Coercion, Capital and European States, AD 990-1992 (Cambridge MA \& Oxford, 1992). It is worth noting, however, that Tilly - a historical sociologist - has attracted criticism from historians, some of whom see the catchy formulation as overly materialistic: see John A. Hall \& Sinisa Malesevic, 'Introduction: wars and nationalisms', in Hall \& Malesevic (eds.), Nationalism and War, 5, 11.

${ }^{92}$ René Lemarchand, 'War and nationalism: the view from Central Africa', in Hall \& Malesevic (eds.), Nationalism and War.

${ }^{93}$ For example, Paul D. Williams, War and Conflict in Africa (Cambridge, 2011); Patrick Chabal, Ulf Engel \& Anna-Maria Gentili (eds.), Is Violence Inevitable in Africa? Theories of conflict and approaches to conflict prevention (Leiden \& Boston, 2005); Preben Kaarsholm (ed.), Violence, Political Culture and Development in Africa (Oxford, 2006); Alfred Nhema \& Paul Tiyambe Zeleza (eds.), The Roots of African Conflicts: the causes \& costs (Oxford, 2008); Alfred Nhema \& Paul Tiyambe Zeleza (eds.), The Resolution of African Conflicts: the management of conflict resolution \& post-conflict reconstruction (Oxford, 2008).
} 
hunger for modernity on the other; at worst, downright hostile, marked by a sense that the deeper past could serve no purpose other than to remind everyone - Africans and foreigners alike - just how barbaric their history was, and how backward things were until Europe showed up to nudge progress along. It was a nuanced and elongated process, not a sudden moment of revelation and transformation; but the upshot was a creeping presentism, a gradual foreshortening of historical trajectories, and a cauterisation of Time itself. To a very large extent it reflected an abiding notion embedded within developmental discourse that war was 'bad' and peace 'good' - especially in Africa, even though Europe's historical experience demonstrated something a little more complicated. 'Peace' itself, of course, is something of a novel concept. ${ }^{94}$ But the idea has taken hold that in Africa's deepest darkest past internecine tribal wars were inimical to the realisation of political and economic 'modernity'. The reality is rather more convoluted, and altogether more nuanced.

In the end, the past became securitised, in order that the nation might survive against the existential threat supposedly posed by history itself: history was a matter of national security, a coalescence of violently sectarian issues which were inimical to modern development and which constituted an existential threat to the political community. ${ }^{95}$ Earlier we discussed Mirambo, who, despite his remarkable political vision and his ambition - not so much ruga ruga as hopeful builder of territorial statehood, no less than Tewodros was mere shifta - has not really endured as historic figure. Mirambo ultimately had no place in a Tanzania in which concepts of modern nationhood were rooted not in a muddy and violent precolonial past although he had a brief resurgence in the 1950s and 1960s as a proto-national hero - but in ideas about modernity, development, the future. What, after all, had Mirambo actually achieved? A violent, short-lived polity which fed off the nefarious trade in people, and which collapsed soon after Mirambo's own death in 1884, was hardly the stuff on which great nations could be built. And thus, for all Nyerere's early enthusiasm for the African past - which was in truth as much a matter of decolonising the curriculum as of any intrinsic interest in precolonial history per se - there was a subtle shift toward the African present, and the future, in the course of the 1970s and 1980s. In Uganda, too, Yoweri Museveni was loath to celebrate the achievements of the precolonial past which was, for the NRM, the source of savage sectarianism, and the positive aims and outcomes of which had been greatly exaggerated. There was nothing glorious about tribal chieftains running around stabbing one another but unable to get to grips with encroaching global modernity.

Ultimately, while certain elements of the deeper past might be mobilised in the service of political and military struggle, longer-range histories were increasingly viewed with ambivalence. At the same time, the wars of the late twentieth and early twenty-first centuries - and the military cultures they produced - have tended to eclipse deeper histories of warfare, not least because of the desire to recover from recent violence and construct nations around 'peace and development' agendas. Still, deeper histories of violence were never very far from the surface, despite the claims to radical violence, and to violent rebirth, in the second half of the twentieth century.

\footnotetext{
${ }^{94}$ Michael Howard, The Invention of Peace and the Reinvention of War (London, 2001).

${ }^{95}$ Barry Buzan, Ole Wæver, \& Jaap de Wilde, Security: A New Framework for Analysis (Boulder CO, 1998); Michael C. Williams, 'Words, Images, Enemies, Securitization and International Politics', International Studies Quarterly, 47 (2003).
} 


\section{BIBLIOGRAPHY}

Alessandrini, Anthony C. (ed.) Frantz Fanon: Critical Perspectives (London, 1999).

Allen, T. \& K.Vlassenroot (eds.) The LRA: myth and reality (London, 2010).

Assefa, Taye. 'Tewodros in Ethiopian historical fiction', Journal of Ethiopian Studies, 16 (1983).

Atkinson, Ronald R. The Roots of Ethnicity: the origins of the Acholi of Uganda before 1800 (Philadelphia, 1994).

p'Bitek, Okot. White Teeth (Nairobi, 1989).

Beattie, John. The Nyoro State (Oxford, 1971).

Bennett, N.R. Mirambo of Tanzania, 1840-1884 (New York, 1971).

Brantlinger, Patrick. 'Victorians and Africans: the genealogy of the myth of the Dark Continent', Critical Enquiry, 12:1 (1985).

Broyon-Mirambo, P. 'Description of Unyamwesi, the territory of King Mirambo, and the best route thither from the East Coast', Proceedings of the Royal Geographical Society, 22:1 (187778).

Burton, Sir Richard Francis. The Lake Regions of Central Africa, 2 vols. (London, 1860).

Buzan, Barry, Ole Wæver, \& Jaap de Wilde. Security: A New Framework for Analysis (Boulder CO, 1998).

Chabal, Patrick, Ulf Engel \& Anna-Maria Gentili (eds.) Is Violence Inevitable in Africa? Theories of conflict and approaches to conflict prevention (Leiden \& Boston, 2005).

Chretien, J.-P. The Great Lakes of Africa: two thousand years of history (New York, 2003).

Chwa, Kabaka Daudi. Education, Civilisation, and Foreignisation in Buganda (orig. published 1935), reproduced in D.A.Low (ed.), The Mind of Buganda: documents in the modern history of a kingdom (London, 1971).

Clapham, Christopher (ed.) African Guerrillas (Oxford, 1998).

Cohen, D.W. The Historical Tradition of Busoga: Mukama and Kintu (Oxford, 1972).

Connell, Dan. Against All Odds: a chronicle of the Eritrean Revolution (Lawrenceville NJ, 1997).

Coleman, James Smoot. 'Tradition and Nationalism in Tropical Africa', in J.S.Coleman (ed.

Richard L. Sklar), Nationalism and Development in Africa: selected essays (Berkeley, 1994). 
Dale, Rev. Henry. The History of the Peloponnesian War (London, 1849).

Davidson, Basil. Which Way Africa? The search for a new society (Harmondsworth, 1964).

Decalo, Samuel. Coups and Army Rule in Africa: motivations and constraints (New Haven \& London, 1990).

Donald, T. Confessions of Idi Amin (London, 1978).

Doyle, Shane. Crisis and Decline in Bunyoro: population ad environment in western Uganda, 1860-1955 (Oxford, 2006).

Eritrean People's Liberation Front. 'National Democratic Programme, Eritrean People's Liberation Front, March 1987', in Lionel Cliffe \& Basil Davidson (eds.), The Long Struggle of Eritrean for Independence and Constructive Peace (Trenton NJ, 1988).

Fanon, Frantz (tr. Constance Farrington). The Wretched of the Earth (London, 1967, 1990).

----. Toward the African Revolution (New York, 1964, 1967).

Gebre-Medhin, Jordan. 'Eritrea (Mereb-Melash) and Yohannes IV of Abyssinia', Eritrean Studies Review, 3:2 (1999).

Golan, Daphna. Inventing Shaka: using history in the construction of Zulu nationalism (Boulder CO, 1994).

Gulliver, P.H. (ed.) Tradition and Transition in East Africa: studies of the tribal element in the modern era (London, 1969).

Gutteridge, W.F. Military Regimes in Africa (London, 1975).

Haile, Semere. 'Historical background to the Ethiopia-Eritrea conflict', in Lionel Cliffe \& Basil Davidson (eds.), The Long Struggle of Eritrean for Independence and Constructive Peace (Trenton NJ, 1988).

Hall, John A. \& Sinisa Malesevic (eds.) Nationalism and War (Cambridge, 2013).

Halliday, Fred \& Maxine Molyneaux. The Ethiopian Revolution (London, 1981).

Hallencreutz, Carl F. 'Thomas Mofolo and Nelson Mandela on King Shaka and Dingane', in Raoul Granqvist (ed.), Culture in Africa: an appeal for pluralism (Uppsala, 1993).

Hamilton, Carolyn. Terrific Majesty: the powers of Shaka Zulu and the limits of historical invention (Cape Town and Johannesburg, 1998).

Hobsbawm, Eric. On History (London, 1997).

Hodgkin, Thomas. Nationalism in Colonial Africa (London, 1956). 
----. 'The relevance of "Western" ideas for the new African states', in J.Roland Pennock (ed.), Self-Government in Modernizing Nations (Englewood Cliffs, NJ, 1964).

Howard, Michael. The Invention of Peace and the Reinvention of War (London, 2001).

----. War in European History (Oxford, 2002).

Human Rights Watch. The scars of death: children abducted by the Lord's Resistance Army in Uganda (New York, 1997).

----. Abducted and Abused: renewed conflict in northern Uganda (New York, 2003).

----. Uprooted and Forgotten: impunity and human rights abuses in northern Uganda (New York, 2005).

Ingrams, Harold. Uganda: a crisis of nationhood (London, 1960).

International Crisis Group. South Sudan: keeping faith with the IGAD peace process, Africa Report No.228, 27 July 2015.

'K.W.' 'The Kings of Bunyoro-Kitara', Uganda Journal, 3:2 (1935).

----. 'The Kings of Bunyoro-Kitara Part II', Uganda Journal, 4:1 (1936).

----. 'The Kings of Bunyoro-Kitara Part III', Uganda Journal, 5:2 (1937).

Kaarsholm, Preben (ed.) Violence, Political Culture and Development in Africa (Oxford, 2006).

Kabaka of Buganda, The Desecration of My Kingdom (London, 1967).

Kabeya, J.B. King Mirambo: one of the heroes of Tanzania (Nairobi, 1976).

Kagwa, A. (tr. \& ed. M.S.M.Kiwanuka). The Kings of Buganda (Nairobi, 1971).

Kamau J. \& A.Cameron, Lust to Kill: the rise and fall of Idi Amin (London, 1979).

Kamugungunu, Lazaro \& A.G.Katate, Abagabe b'Ankole (Kampala, 1955).

Kapuscinski, Ryszard. The Emperor: Downfall of an Autocrat (London, 2006; $1^{\text {st }}$ ed. 1978).

Kopytoff, Igor (ed.) The African Frontier: the reproduction of traditional African societies (Bloomington \& Indianapolis, 1987).

Kyaminyawandi, Augustine. The Faces of the Rwenzururu Movement (n.p., 2001).

Kyemba, Henry. State of Blood: the inside story of Idi Amin's reign of fear (London, 1977).

Lamphear, John. 'The evolution of Ateker "New Model” Armies: Jie and Turkana', in K.Fukui \& J.Markakis (eds.), Ethnicity and Conflict in the Horn of Africa (London, 1994). 
Lawrance, J.C.D. The Iteso: fifty years of change in a Nilo-Hamitic Tribe of Uganda (London, 1957).

Lee, J.M. African Armies and Civil Order (London, 1969).

Lemarchand, René. 'War and nationalism: the view from Central Africa', in John A. Hall \& Sinisa Malesevic (eds.), Nationalism and War (Cambridge, 2013).

Leopold, Mark. Inside West Nile: violence, history and representation on an African frontier (Oxford, 2005).

Lonsdale, John. 'Some origins of nationalism in East Africa', Journal of African History, 9:1 (1968).

Low, D.A. Buganda in Modern History (London, 1971).

Lubogo, Y.K. 'A History of Busoga' (translated \& unpublished manuscript in Makerere University Library, Kampala, 1960).

Lunyiigo, Samwiri Lwanga. Mwanga II: resistance to imposition of British colonial rule in Buganda, 1884-1899 (Kampala, 2011).

Mackay, A.M. A.M.Mackay, Pioneer Missionary of the Church Missionary Society to Uganda (London, 1890).

Mandela, Nelson. Long Walk to Freedom (London, 1995).

Martin, D. General Amin (London, 1974).

Mazrui, Ali. 'The social origins of Ugandan presidents: from king to peasant warrior', Canadian Journal of African Studies, 8 (1974).

----. 'Soldiers as Traditionalizers: military rule and the reafricanisation of Africa', in Ali Mazrui (ed.), The Warrior Tradition in Modern Africa (Leiden, 1977).

McDougall, James. History and the Culture of Nationalism in Algeria (Cambridge, 2006).

Médard, Henri. La Royaume du Buganda au XIXe siècle (Paris, 2007).

Melady, T. \& M. Melady, Idi Amin Dada: Hitler in Africa (Kansas City, 1977).

Milkias, Paulos \& Getachew Metaferia (eds.), The Battle of Adwa: Reflections on Ethiopia's Historic Victory Against European Colonialism (New York, 2005).

Miti, James. 'A History of Buganda' (unpublished manuscript, SOAS Library, London, c.1938).

Morris, H.F. The Heroic Recitations of the Bahima of Ankole (Oxford, 1964). 
Museveni, Yoweri. 'Fanon's theory on violence: its verification in liberated Mozambique', in N.M.Shamuyarira (ed.), Studies in Political Science, 3 (Dar es Salaam, 1974).

----. Sowing the Mustard Seed: the struggle for freedom and democracy in Uganda (Oxford, 1997).

----. What is Africa's Problem? (Minneapolis, 2000).

Ngoga, Pascal. 'Uganda: the National Resistance Army', in C. Clapham (ed.), African Guerrillas (Oxford, 1998).

Nhema, Alfred \& Paul Tiyambe Zeleza (eds.) The Roots of African Conflicts: the causes \& costs (Oxford, 2008).

----. The Resolution of African Conflicts: the management of conflict resolution \& post-conflict reconstruction (Oxford, 2008).

Nyakatura, John (ed. G.N.Uzoigwe). Anatomy of an African Kingdom: a history of BunyoroKitara (New York, 1973).

Nyerere, Julius K. 'Ujamaa': The Basis of African Socialism (Dar es Salaam, 1962).

Oliver, R. 'Discernible developments in the interior, c.1500-1840', in R.Oliver \& G.Mathew (eds.), History of East Africa Vol I (Oxford, 1963).

Orlowska, Izabela. 'Forging a nation: the Ethiopian millennium celebration and the multiethnic state', Nations and Nationalism, 19:2 (2013).

Parker, Geoffrey. The Military Revolution: military innovation and the rise of the West, 15001800 (Cambridge, 1988, 1996).

Pateman, Roy. Eritrea: Even the Stones are Burning (Lawrenceville NJ, 1990, 1998).

Peterson, D.R. 'States of Mind: Political History and the Rwenzururu Kingdom in Western Uganda', in D.R.Peterson \& G.Macola (eds.), Recasting the Past: history writing and political work in modern Africa (Athens OH, 2009).

Porter, Patrick. Military Orientalism: Eastern war through Western eyes (London, 2009).

Rao, R. 'Re-membering Mwanga: same-sex intimacy, memory, and belonging in postcolonial Uganda', Journal of Eastern African Studies, 9:1 (2015).

Ranger, T.O. (ed.) Emerging Themes of African History (Nairobi, 1968).

----. 'Connexions between "Primary Resistance" movements and modern mass nationalism in East and Central Africa', Parts I \& II, Journal of African History, 9:3 \& 9:4 (1968).

----. 'Towards a Usable African Past', in Christopher Fyfe (ed.), African Studies since 1945: a tribute to Basil Davidson (London, 1976). 
Reid, Richard. Political Power in Pre-Colonial Buganda: economy, society and warfare in the nineteenth century (Oxford, 2002).

----. 'Revisiting primitive war: perceptions of violence and race in history', War and Society, $26: 2$ (2007).

----. Warfare in African History (New York, 2012).

----. 'The Fragile Revolution: rethinking war and development in Africa's violent nineteenth century', in E.Akeampong, R.H.Bates, N.Nunn \& J.Robinson (eds.), Africa's Development in Historical Perspective (Cambridge, 2014).

----. 'Writing Eritrea: history and representation in a bad neighbourhood', History in Africa, 41 (2014).

----. 'Ghosts in the Academy: historians and historical consciousness in the making of modern Uganda', Comparative Studies in Society and History, 56:2 (2014).

----. 'States of Anxiety: history and nation in modern Africa', Past and Present, 229 (2015).

Reyntjens, Filip. The Great African War: Congo and regional geopolitics, 1996-2006 (Cambridge, 2009).

Richardson, M.L. After Amin: the bloody pearl (Atlanta, 1980).

Roscoe, John. The Baganda: an account of their native customs and beliefs (London, 1911).

----. Twenty-Five Years in East Africa (Cambridge, 1921).

----. The Bakitara or Banyoro (Cambridge, 1923).

Rowe, John. 'Roscoe's and Kagwa's Buganda', Journal of African History, 8:1 (1967).

----. 'Myth, memoir and moral admonition: Luganda historical writing, 1893-1969', Uganda Journal, 33:1 (1969).

Samuel, Raphael. Island Stories: Unravelling Britain. Theatres of Memory, Vol II (London \& New York, 1998).

Schivelbusch, Wolfgang. The Culture of Defeat: on national trauma, mourning, and recovery (London, 2003).

Schoenbrun, David. 'Conjuring the Modern in Africa: durability and rupture in histories of public healing between the Great Lakes of East Africa', American Historical Review, 111:5 (2006).

Schwab, Peter. Ethiopia: Politics, Economics, and Society (London, 1985).

Speke, J.H. Journal of the Discovery of the Source of the Nile (Edinburgh \& London, 1863). 
Stanley, H.M. Through the Dark Continent, 2 vols. (London, 1878, 1899).

Steinhart, E.I. Conflict and Collaboration: the kingdoms of western Uganda, 1890-1907 (Princeton NJ, 1977).

Suso, Bamba \& Banna Kanute (ed. Lucy Duran \& Graham Furniss), Sunjata (London, 1974, 1999).

Syahuka-Muhindo, A. The Rwenzururu Movement and the Democratic Struggle (Kampala, 1991).

Thompson, Gardner. Governing Uganda: British colonial rule and its legacy (Kampala, 2003).

Tilly, C. Coercion, Capital, and European States, AD 990-1992 (Malden MA \& Oxford, 1992).

Tiruneh, Andargachew. The Ethiopian Revolution, 1974-1987: a transformation from an aristocratic to a totalitarian society (Cambridge, 1993).

Uzoigwe, G.N. 'The warrior and the state in precolonial Africa', in A.A.Mazrui (ed.), The Warrior Tradition in Modern Africa (Leiden, 1977).

Williams, Michael C. 'Words, Images, Enemies, Securitization and International Politics', International Studies Quarterly, 47 (2003).

Williams, Paul D. War and Conflict in Africa (Cambridge, 2011).

Winter, Jay. Sites of Memory, Sites of Mourning: the Great War in European cultural history (Cambridge, 1995).

Wylie, Dan. Myth of Iron: Shaka in History (Scottsville, 2006).

Young, John. Peasant Revolution in Ethiopia: the Tigray People's Liberation Front, 1975 1991 (Cambridge, 1997).

Zimbe, B.M. 'Buganda ne Kabaka [Buganda and the King]', (unpublished ms., Makerere University Library, Kampala, c.1939). 